The Chittagong Univ. J. B. Sci., Vol. 4(1 \&2):25-39, 2009.

\title{
SURVIVAL STRATEGIES AMONG EROSION-INDUCED DISPLACEES AT HAIMCHAR UPAZILA, CHANDPUR DISTRICT, BANGLADESH.
}

\author{
MD. ABU TALEB ${ }^{1}$, MD. HUMAYUN KABIR ${ }^{2}$ AND MD. MUHIBBULLAH*3 \\ Department of Geography and Environmental Studies, University of Chittagong and Department \\ of Geography and Environment, University of Dhaka.
}

\begin{abstract}
The present study has been taken to discuss the human dimension of the phenomenon and argues the need for a better understanding of the mechanisms underlying erosion-induced people at Haimchar upazila in Bangladesh. The paper emphasizes the importance and need for looking into the phenomena of riverbank erosion, course shifting tendency, population displacement and its impact in socio-economic condition at national scale in order to understand and competently deal with the problem. In this study both primary and secondary data have been used. The primary data include field survey and victims' opinion survey from erosion-affected villagers through questionnaire. During the last three decades about 35,605 peoples were displaced in the study area due to river bank erosion. Most of the affected people were living on the embankment. It was noted that there is a great degree of uncertainty as to when land would be devoured by the river; and on an average people were affected 3 times during the last three decades. Some of the techniques to survival strategies for the affected households are also discussed in this study.
\end{abstract}

Keywords: Survival strategy, Erosion, Displacees, Haimchar, Chandpur District.

\section{INTRODUCTION}

The rivers of Bangladesh have profound effect on the land, people and resources along their courses. Riverbank erosion destroys standing crops, farmland and homestead land and every year millions of people are affected. It is estimated that about $5 \%$ of the total floodplain of Bangladesh is directly affected

1 Postgraduate student, Department of Geography and Environment, University of Dhaka.

2 Assistant Professor, Department of Geography and Environment, University of Dhaka.

3 Assistant Professor, Department of Geography and Environmental Studies, University

of Chittagong.

* Corresponding Author.

$-5$ 
TALEB ET AL.

by erosion and bank erosion is taking place in about 94 out of 489 upazilas of the country (Banglapedia 2007). Recent satellite images studies of the GangesBrahmaputra and Meghna rivers between 1982 and 2004 show that 106,300 hectares land was lost by erosion, while only 19,300 hectares was accreted. This amounted to a net loss of 8,700 hectares annually, most of which is agricultural land (Abrar and Azad 2004). Riverbank erosion is very unpredictable in nature and is very deceptive. After an initial disruptive phase, all of a sudden everything may stop. It may appear that erosion had caused. With a break of a few hours suddenly massive blocks of land may again begin to get washed away. In these cases losses become more pronounced because potential victims tend to believe that lull in erosion as cessation of disruptive activity. In the present study an attempt has also been made to identify the causes of human replacement due to riverbank erosion and focus the relationship between erosion hazard and dynamics of human adjustment with this hazardous situation to gain a consensus regarding the phenomenon for the affected people and lastly draw comprehensive techniques for survival strategies among the erosion- induced displacees in the study area.

\section{MATERIALS AND METHODS}

\section{Study area}

Haimchar upazila of Chandpur District is located in the south eastern part of Bangladesh and about $20 \mathrm{~km}$ away from the district headquarter of Chandpur. It lies between $23^{\circ} 02^{\prime}$ and $23^{\circ} 08^{\prime}$ North latitude and $90^{\circ} 34^{\prime}$ and $90^{\circ} 40^{\prime}$ East longitudes (Banglapedia 2007). It is bounded by Chandpur Sadar and Bhedarganj upazila on the north, Hizla upazila on the south, Raipur and Faridganj_upazilas on the east, and Gosairhat upazila on the west (Map 1). Haimchar is a small upazila and covers an area of $174.48 \mathrm{sq} \mathrm{km}$. of which $72.99 \mathrm{sq} \mathrm{km}$ is reverine and the density of population in the study area is 717 per sq $\mathrm{km}$ (BBS 2006). The Haimchar upazila of Chandpur District is one of the rapid erosional zones in lower Meghna where land crumbling is as common as the swirling rivers. About 10 villages have been totally eroded away during the last few decades (Taleb 2007). In this stretch Haimchar upazila frequently affected by river erosion has been taken as a case study area for this study. The study area includes Nilkamal, Charbhairabi, Gazipur union of Haimchar upazila (Map 1). 
SURVIVAL STRATEGIES AMONG EROSION

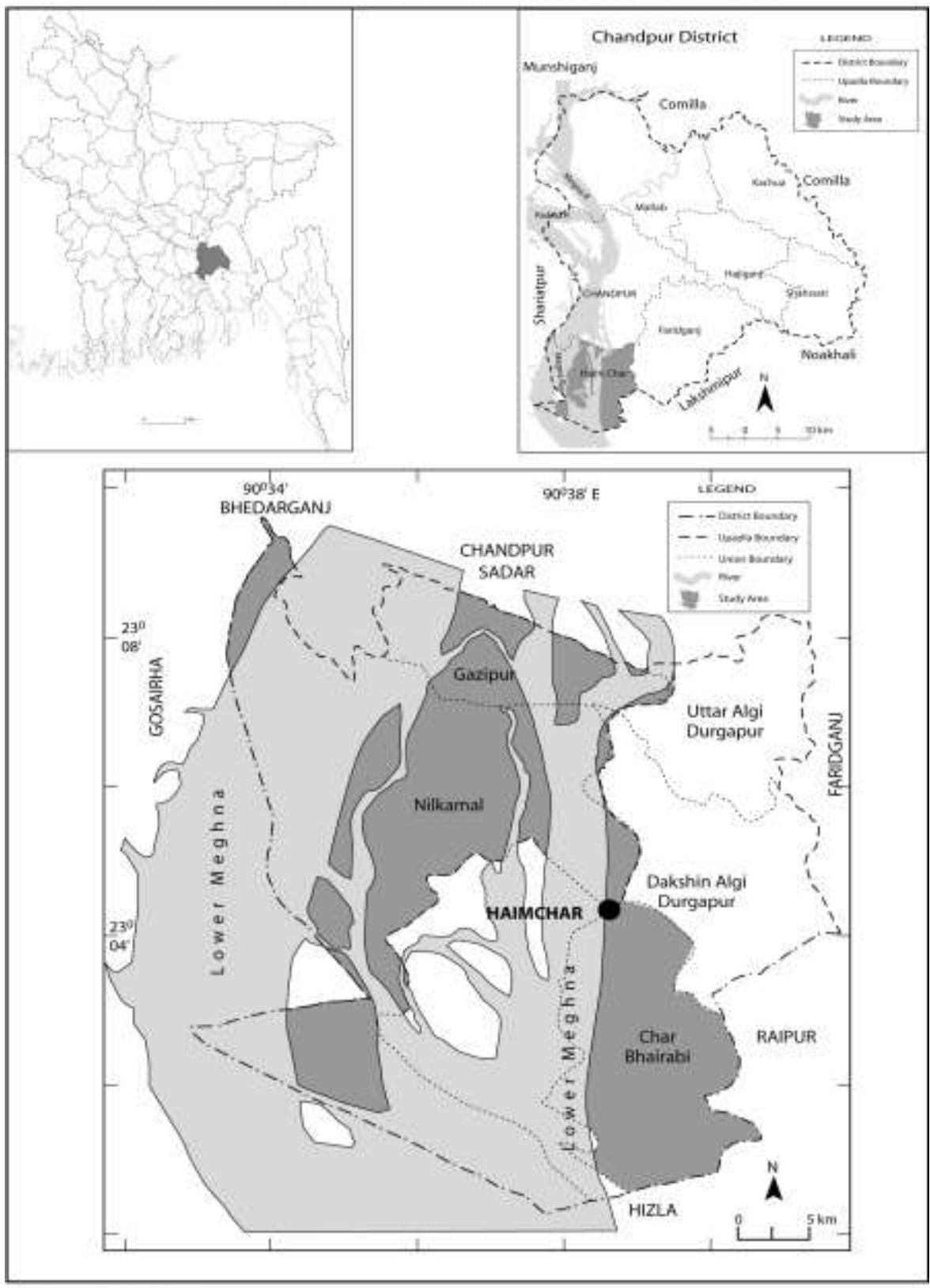

Source : Banglapedia, 2607

MAP 1. STUDY AREA (HAIMCHAR UPAZILA IN CHANDPUR DISTRICT) 
TALEB ET AL.

\section{Sources of data}

In this study both primary and secondary data have been used.

Primary sources

It includes field survey and victims' opinion survey from erosionaffected villagers through questionnaire.

(i)Field survey

A field survey was done to collect the primary data for this study. A number of experts in the respective fields were interviewed face to face. This information was matched with the secondary data to study the incompetence of the primary data.

(ii)Victims' opinion survey through questionnaire

To incorporate the views of the erosion- induced displacees a set of questionnaire was prepared and produced directly to the people in the study area. The sample size was 30 questionnaires. The survey was conducted in the month of November 2007.

\section{Secondary sources}

The secondary data on population and related aspects were collected from various published and official sources. Many articles related to research work either published or unpublished have been frequently used. The Bangladesh Bureau of Statistics mostly supplied data on population for the present study. The socio-economic data were provided by UNO office at Haimchar upazila. Besides these, the related old records of different offices and the news from daily newspaper have been utilized.

\section{RESULTS AND DISCUSSION}

River bank erosion and changing morphology in the study area

The lower Meghna carries the combined flow of the river Padma and upper Meghna. The erosion rates of lower Meghna in the left bank around the study area during the period of 1929 to 2007 are shown in the figure (Figure 1). It is observed from the figure 1 that the left bank of the lower Meghna at Haimchar has been eroding continuously. The rate of erosion and its location has however changed from year to year. As a result the downstream of Chandpur zila town is shifted at an average rate of 75 meter per year during the period 1929 to 1988 and 


\section{SURVIVAL STRATEGIES AMONG EROSION}

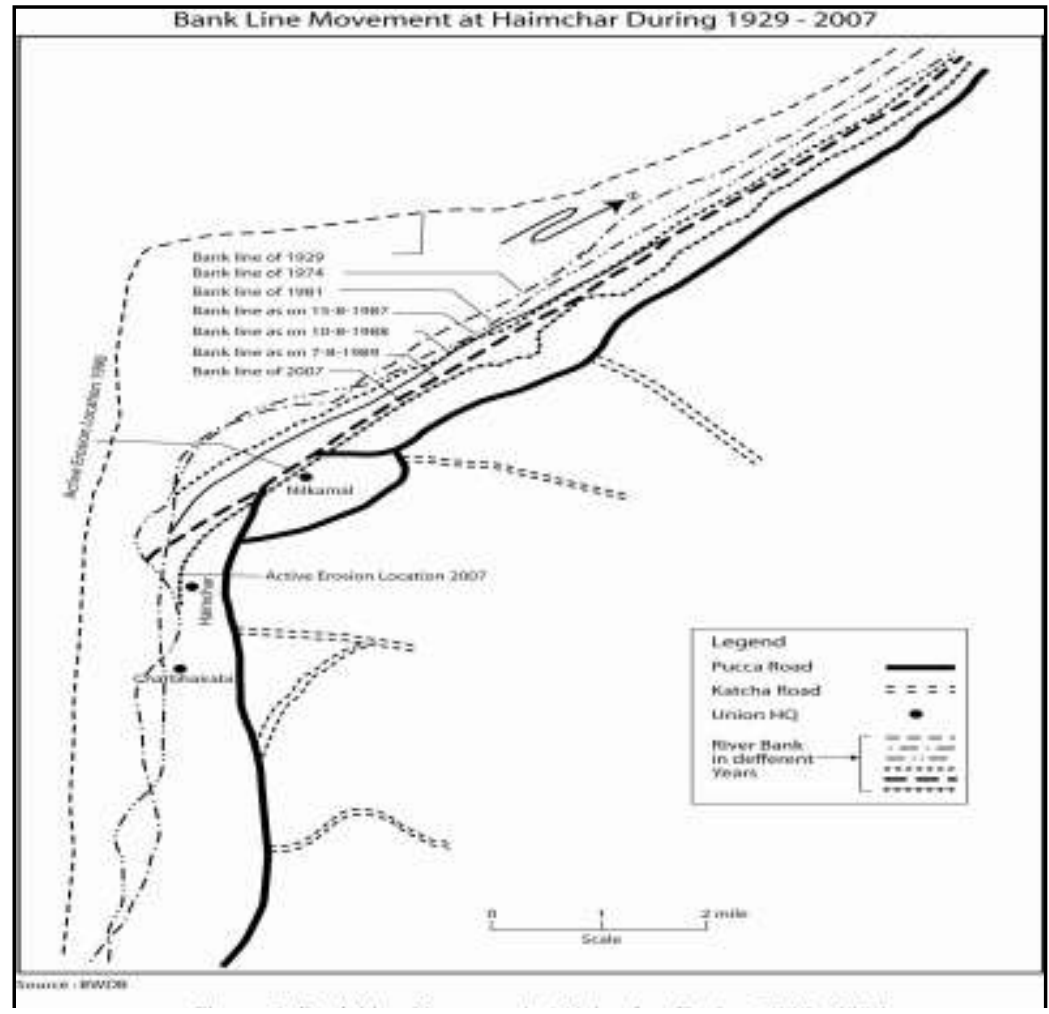

FIGURE 1. BANK LINE MOVEMENT AT HAIMCHAR DURING 1929-2007

at an average rate of 3.92 meter per year during the period 1992 to 2000 due to mass erosion of the river.

Population displacement due to riverbank erosion in the study area

It is more difficult to define the concept of population displacement than that of population migration. Because population displacement recycles naturally between char land and main land; when the main land erodes then the population migrates to the char land. So, we can estimate the number of population displacement by comparison of the population census of 1991 with that of 2001. According to the population census in1991 the total number of population of Gazipur union of Haimchar upazila was 5442 (male 2794 and female 2648), Nilkamal union had 27473 (male 14277 and female 13196) and in the Charbhairabi union under Haimchar upazila the total number of population was 28737 (male 14503 and female 14234) are found (Figure 2). But in 2001 census it is observed that the total number of population decreased in Gazipur and Nilkomal union which was 3946 and 25386 respectively (Figure 3). 
TALEB ET AL.

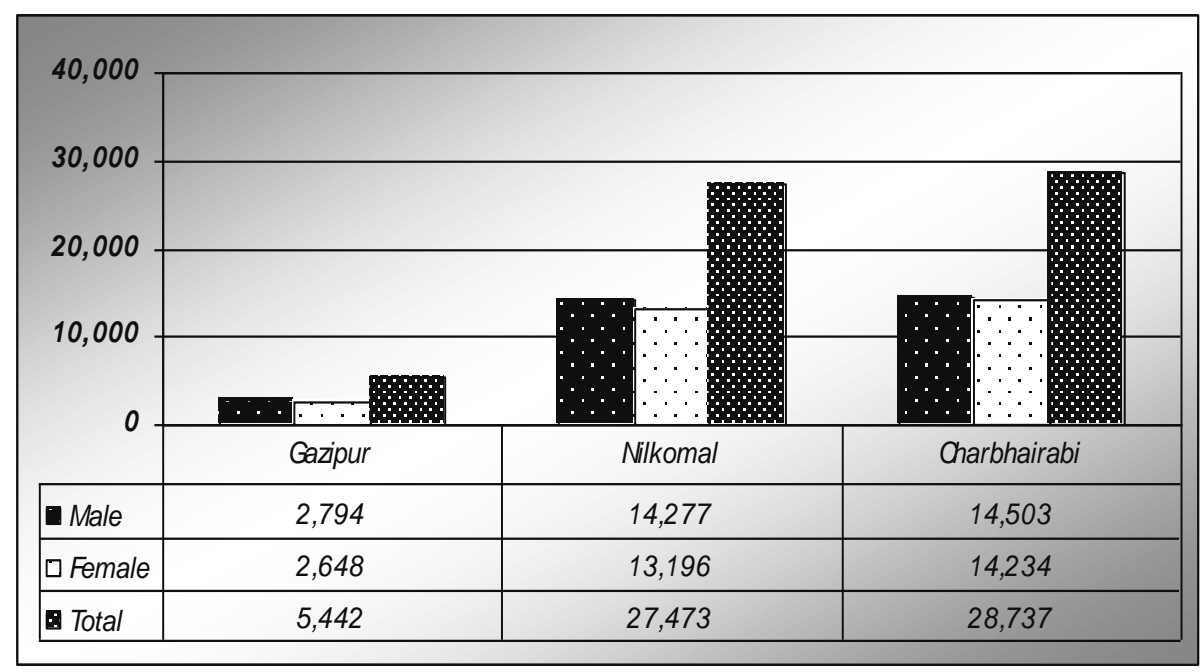

Source: Population Census, 1991

FIGURE 2. POPULATION DISTRIBUTION IN DIFFERENT UNION OF HAIMCHAR UPAZILA IN 1991.

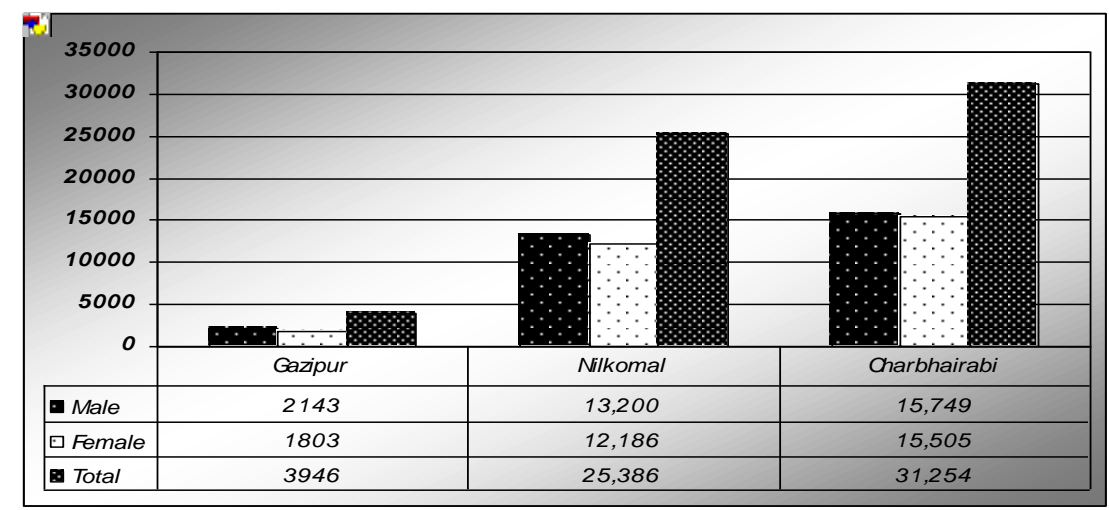

Source: Population Census, 2001

FIGURE 3. POPULATION DISTRIBUTION IN DIFFERENT UNION OF HAIMCHAR UPAZILA IN 2001.

From the comparison between population census 1991 and 2001, it is indicating that in 1991 the total number of population in Gazipur and Nilkamal union was higher than the census of 2001 (Figure 4). But it was abnormal demographic situation because population growth was 1.07 according to population census 1991. This abnormal situation is created by the population displacement due to riverbank erosion in the study area. 


\section{SURVIVAL STRATEGIES AMONG EROSION}

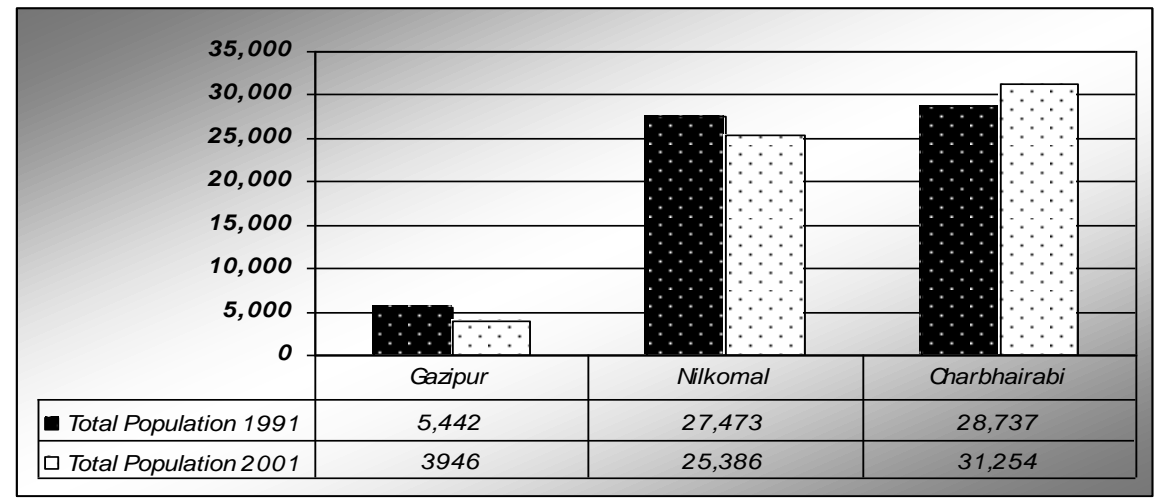

Source: Population Census, 1991 and 2001

FIGURE 4. COMPARISON BETWEEN POPULATION CENSUS 1991 AND 2001 IN THE STUDY AREA.

It is also observed since the last three decades that about 35,605 people were displaced in the study area due to river bank erosion (Figure 5). The highest number of people was displaced (6000 people) in 1988 which indicates the severe condition of erosion in the study area. Accordingly a huge number of people are displaced in the study area i.e. 4000 in 1987, 5000 in 1998 and 4000 in 2004 (Figure 5).

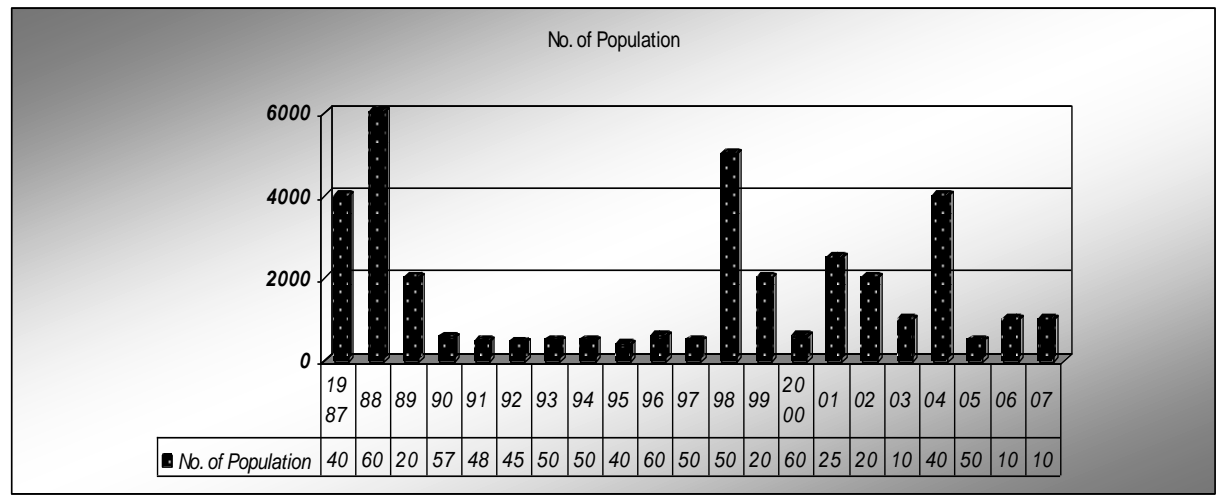

Source: Revenue office of Haimchar, 2007

FIGURE 5. YEAR WISE POPULATION DISPLACEMENT DUE TO RIVERBANK EROSION IN THE STUDY AREA.

\section{Existing survival strategies of displacees in the study areas}

It is observed that most of the displacees in the study area are found on their own rest of the land. Some of them were living on the nearby embankment, some stayed on land that belonged to other people, while others shared their relative's dwellings. Only a few had the resources to buy plot of land and start 
TALEB ET AL.

afresh. Usually the neighboring communities provided great help. They gave them space and helped them to build their new shelter. Some voluntarily contributed their labor. In many instances within a short time those who sought shelter in embankment or schools found alternative shelters. On the other hand, settlement pattern in riverbank erosion-prone areas at Haimchar suggests that some household move to safe zones and build safer settlement, but many merely relocate within the same area that has either been already affected or bears known vulnerable characteristics. Most of the settlements are located in the middle part on the bank. Most of the respondents locate their settlement in the erosion prone area and wait to occupy emerging char. Initiation of settlement in the char land usually does not take place before a laps of three years after the emergence of the char. But present field observation indicates that displacees moved into the char as early as one year after their emergence. About 53.33 percent of the total respondents have relocated their settlement. In the erosion prone area 26.67 and 20 percent people have been relocated (Taleb 2007). Physical factors operate as the dominant force for shifting settlement. Sometimes social forces override the physical factors. The char environment itself is so uncertain that whenever there is any physical change, it immediately affects the settlements. The first stage is termed as the 'formation stage' and it is the period when a char emerges and displacees wait for occupancy. This is one of the main reasons to settle in the vulnerable area.

\section{Homestead shifting}

Displacement scenario in the following figure-6 simply indicates the worsened situation in the study area where people had no option but to accept displacement as something fated.

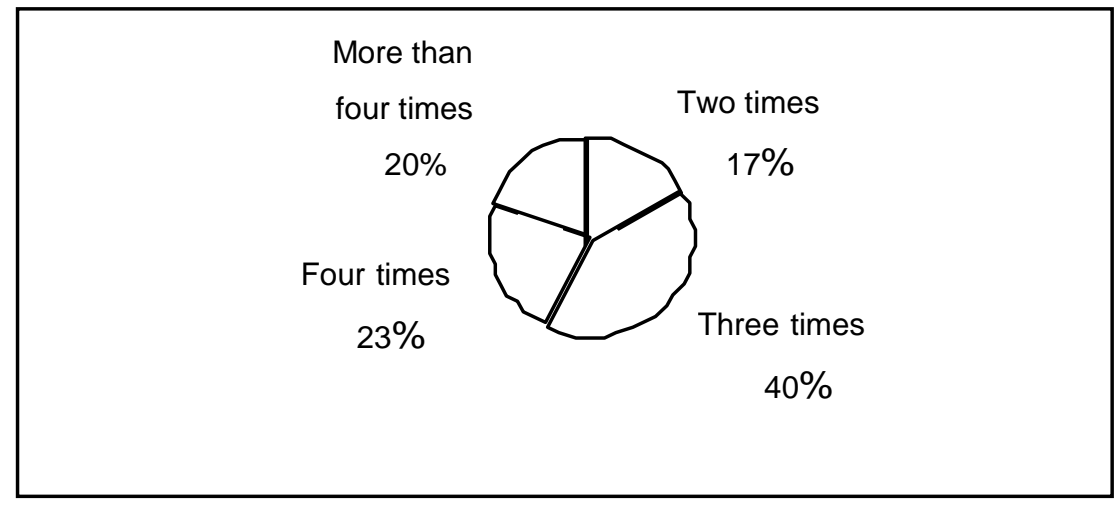

Source: Revenue office of Haimchar upazila, 2007.

FIGURE 6. FREQUENCY OF HOMESTEAD SHIFTING TYPES IN THE STUDY AREA. 


\section{SURVIVAL STRATEGIES AMONG EROSION}

The above figure demonstrated the frequency of shifting of homestead in the study area. It is clear that all the settlements in the study area are recorded dwelling units, which ranged from 2 to 4 times in some case' it is more than 4 times since the last three decades.

\section{Migration pattern}

The displacement is primarily confined within the villages of the same union where displacees moved from the villages inside the union. Intra-union displacement is frequent, as displacees tend to take shelter in the villages within the same union Nilkomal and Gazipur. While intra union displacement is quite striking at Charbhairabi and Nilkomal. The three unions of the study area are showing that $36 \%$ of displacees were displaced from the villages out side the union but within the same upazila and $44 \%$ of displacees moved from within the villages of the same union (Figure 7). This situation establishes the facts that displacees generally do not move long distance and still prefers to stay in the hazardous environment though it is found that about $20 \%$ of displacees moved to another city forever and do not come back to their own district.

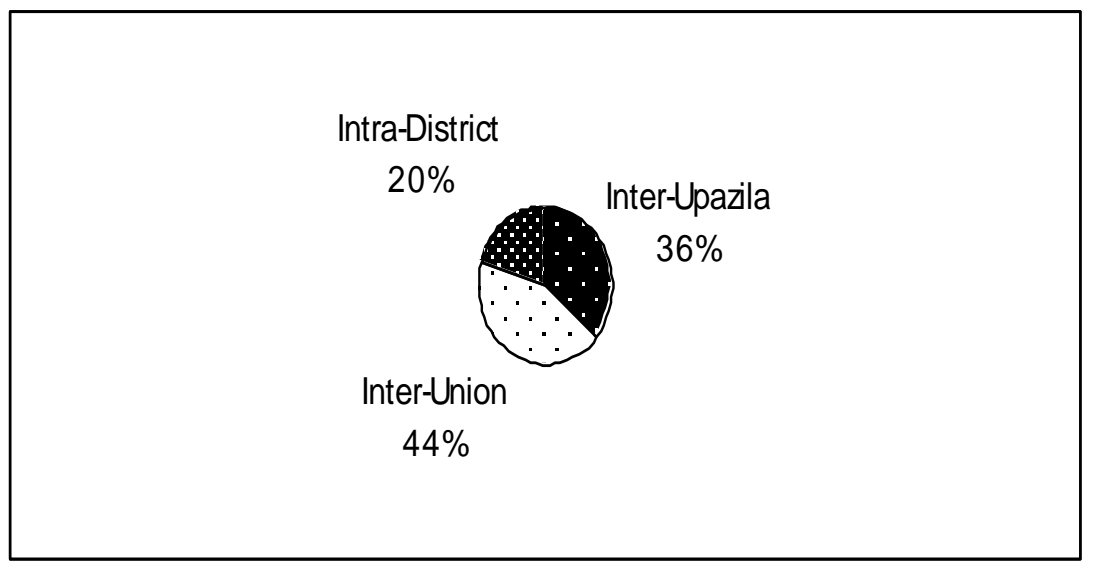

Source: Field survey, 2007

FIGURE 7. MIGRATION PATTERN DUE TO RIVERBANK EROSION IN THE STUDY AREA.

\section{Further migration}

Most of the respondent's resettled in the neighboring areas when displaced by riverbank erosion. The explanation of this situation is that they generally tend to stay in areas closer to the original places of residence. Hope of recovery of 
TALEB ET AL.

land in emerging char areas and desire to live with their own society make them relatively less mobile and often almost permanently settled in rural slum conditions. Although many tend to survive by dint of enduring physical hardship, shared poverty and economic sufferings, the quality of life, living and habitat conditions tend to deteriorate beyond normal comprehension. It is observed in the study that respondents want to resettle hazardous areas, because they have severe hardship in the char, no hope of recovery of land in emerging char areas, the uncertainty of the char environment. Some household do move to safe zones and build safer settlement. Even though, $14 \%$ of the respondents plan to move somewhere. This was due to dissatisfaction with the present environmental conditions and wishing to get better to shelter and jobs elsewhere. Some of the specific reasons for moving elsewhere have been identified by respondents. There are (i) Fear of recurrence of erosion (ii) Lack of employment and social security and prestige and (iv) Mal-adjustment with the local community.

\section{Relative migration}

It is observed by the field investigations and questionnaire survey that about $6 \%$ of the respondent's relatives migrated in the neighboring areas and $66 \%$ migrate on the nearly embankment. Causes of out migration are attributed to limited ability to migrate against loss of land to riverbank erosion, uncertainty of repossession of re-emerged land and perceived and real inequalities in economic opportunities. The migration of the displacement is primarily associated with socio-culture dynamics adjustment to riverbank erosion. The displacees migration is related to (i) lack of alternative places of shelter (ii) economic inability to migrate to more distant places, (iii) the proximity of the urban destination and (iv) the existence of social contracts with other migrants. Also the hope of regaining access to their eroded land should it re-emerge encourages erosion victims to close to their places of origin. One skill that almost all displacees possess is their agricultural experience. Government should, therefore give priority to the resettling displacees to emerged char land. However, improved land tenure legislation and stricter policing of legal claims to dispositional land by powerful landlord must accompany any such policy.

Possible technique for survival strategy among erosion induced people in the study area

Concerned experts, through their opinion and researches have suggested some techniques for survival of displacees. These are given in the following sections. 


\section{SURVIVAL STRATEGIES AMONG EROSION}

\section{Previous experience}

Previous experience and duration of residence have a positive contribution to awareness of future riverbank erosion and adjustment measures. People make their decisions on the assumption that a particular risk will appear for which they have some experience; thus all coping strategies for adverse events have a perceived precedent. Abrar and Azad (2004) argues that although people on floodplains appear to be very much 'prisoners of experience', the effect of such experience does not consistently proceed in the direction of taking individual action to reduce damage. They have observed that people tend to be consistently optimistic in their assessment of hazard occurrences.

\section{Attachment to place and potential hazardousness of an area}

In the recent times there is a significant rise of natural disasters despite improvements in preparedness and mitigation responses. Alexander (1993) identified four reasons of this. Firstly, geographical inertia and lucrative economic returns in specific location have led to a continued inhabitance of past and potential disaster zones. Capital may have subordinated all other concerns in our commodity driven global order; placing economies at the top of the social need hierarchy. Secondly, particular risks or dangerous conditions have often been accentuated by managerial or bureaucratic malpractice. Thirdly, the process of physical capital accumulation and encroachment into natural regions has led to capital and population concentration in hazardous locations. Finally there has been a lack of understanding and recognition of the need for a concerted effort to address extremely adverse events. The copping mechanisms of the displaced population depends on both individual and social-collective responses to riverine hazard and involve three variables, socio-economics structure, previous experience of displacement due to river encroachment and hazardousness of current residence by zone. Coping with riverbank erosion is associated with an individual's positioning the socio-economical structure such as educational status, income level, land ownership size and occupational status.

\section{Economic and planning direction of bank erosion}

Siddiki (2002) had suggested that the control of riverbank erosion and population displacement is quite impossible. Therefore, displaces are forced to adjust with the event. Coping with the event was characterized with traditional social and economical practice, beliefs and attitude and also certain orthodox ideas about the hazard itself handed down from generation to generation. The low level of technology and the absence of any public or external input in the erosion affected areas result in the folk or traditional process of adjustment, which are 
TALEB ET AL.

primitive and rudimentary in the nature. Individual nature, initiatives and responsibilities of adjustment mostly distinguish the affected villager's responses to erosion hazard. It is highly pertinent that more than 65 percent of the affected population did not show eagerness to move elsewhere for subsistence; rather they hoped to take positive measures peculiar to the level of their existence. Even when severe erosion takes place in the area, affected people followed 'wait and see' policy before adopting any survival strategies. Secondly, though mobility in riverbank erosion was rarely seen as option for adjustment but when the event occurred with increasing severity, it was no longer safe to remain in the affected areas, and the affected populations were bound to make a move but generally in places closer to the affected areas. They moved possibly with some moveable properties needed for the survival for the certain period. With the whole series of miscellaneous diversified adjustment mood adopted by the displacees, organized measures, like government aids- both short and long term, better warning system, quick evacuation programs and relief activities, could definitely reduce the damaging effects due to riverbank erosion. But the measures were mostly not available to the displacement.

\section{Resettlement of the displacees}

Haque and Zaman (1989) suggested that for any natural hazards the emergency operation from the government and other aid agencies envisage necessary relief and assistance to the affected people for the rehabilitation. But the respondents do not mention any notable relief works either by the government or other agencies. The resettlement of the displaced people has been the ultimate option supported by displacees. As born out from these studies, displacees longed to resettle in the areas of newly accreted land or char lands which once belonged to them. These lands have remained beyond their reach as various social and economical circumstances made displacees unable to recover them under the prevailing laws related with char land reclamation as well as those on land tenure system for the char lands.

\section{Remedial policies}

Abrar and Azad (2004) had focused attention on villages which are liable to erosion with a sizeable population. The control of erosion is in fact a remote possibility in a short-run planning and the opportunities to relocate displacees in a permanent way are limited. Therefore, the rehabilitation program should be taken immediately. The erosion hazard is possible to be minimized by adopting a number of physical and socio-economic planning measures. If these are not 


\section{SURVIVAL STRATEGIES AMONG EROSION}

undertaken the problem associated with the river erosion will continue to increase affecting the human habitat and the economy as well of the area concerned. By knowing the causes and the consequence of river erosion and the area liable to erosion it would be possible to suggest remedial policies, which again must be sieved through the particular geographical situation where they are to be implemented. The initial stage of the planning process should be designed in the context of long term planning allowing the involvement of the local expertise as well as reflecting aspirations phenomena at the regional scale ranged from the broad to the specific aspects.

\section{Checking of river erosion}

Siddiki (2002) had suggested that the opportunities and possibilities of checking riverbank erosion were completely limited, so efforts should be made to control it with available means. Destruction from river erosion may be lessened by the implementation of various measures. Areas prone to erosion should be identified and possible necessary structural measures, afforestation on and around the embankment and river bank may be undertaken in phases.

\section{Rehabilitation program}

Zaman (1989) has suggested that the rehabilitation program is an immediate need for displacees. Functional initiatives sponsored by both the government and NGO or individuals are to be made to develop and ensure a temporary living arrangement in the worst years for displacees, to upgrade the conditions for the landless displacees. Aid and support may also be allocated to encourage landless displacees, and to upgrade their conditions to ascertain and to organize the distribution and use of newly reclaimed lands. For resettlement purpose accreted lands should be given to the original owners, and transfer should be easy, simple and rapid so that reallocation of land takes little time providing the opportunity of rapid recovery and resettlement program in areas concerned. Increased research on the possible adjustment in terms of river erosion, land reclamation and rehabilitation including low-cost housing program certainly would add insight considerably towards lessening the loss caused by such disastrous effects.

\section{Employment opportunities for the displacees}

Haque (1991) had shown that the scope of finding employment is practically nil because of the number of affected people far outstrips the number of employment's available. Still then there may be a unique opportunity to revitalize the rural industry of traditional craftsmanship. Landless unskilled labor 
TALEB ET AL.

may be employed in different activities under the scheme of food for works programs. The NGO's may take initiatives to employ these unemployed-affected populations to work in special income generating projects. As long term measures, new agriculture techniques and practices of new crops in sandy char soils are to be evolved which may allow a quick recovery of employment and income levels on the posits lands.

\section{CONCLUSION}

The major thrust of the research has been to determine the population displacement and survival strategies due to riverbank erosion hazard at Haimchar Upazila, based on the results of the questionnaire survey concerning the relationship between population displacement and their socio-economic conditions. Field investigation indicates that, most of the affected people now living on the embankment lost their land, homesteads and belongings. Significantly house construction materials in most of the cases were successfully removed from the threat of damage. On the other hand, crop land is always threatened by riverbank erosion. It was noted that there is a great degree of uncertainty as to when land would be devoured by the river and that on an average respondent households were affected by 3 times. Respondents also noted that they received support from their relatives, friends and elite of the new locality. Suggested remedial policies for erosion especially in regional perspectives and the reflections of the respondents are not the only solutions in this regard, but may need much more refinement and further adjustment to the very local areas.

\section{REFERENCES}

ABRAR, C.R. AND AZAD, S.N. 2004. Coping with Displacement Riverbank Erosion in North- west of Bangladesh, Dhaka: RMMRU.

BANGLADESH BUREAU OF STATISTICS (BBS).1991. Statistical Yearbook of Bangladesh, Government of the People's Republic of Bangladesh, Dhaka.

BANGLADESH BUREAU OF STATISTICS (BBS). 2006. Chandpur District, Census Preliminary Report, 2001. Population Census wing, Ministry of Planning, Dhaka.

BANGLAPEDIA. 2007. Location Bangladesh, Retrieved May 2008 from the Banglapedia Website: http://banglapedia.search.com.bd/HT/T0046.HTM. 


\section{SURVIVAL STRATEGIES AMONG EROSION}

HAQUE, C.E. 1991. Human Responses to Riverbank Erosion Hazard in Bangladesh: Some Lesson from Indigenous adjustment Strategies, in K.M. Elahi, K.S. Ahmed and M. Mafizuddin (eds): Riverbank erosion, Flood and Population Displacement in Bangladesh, Dhaka: Riverbank Erosion Impact Study, Jahangirnagar University.

HAQUE, C. AND ZAMAN, M. 1989. Coping with riverbank erosion hazard and displacement in Bangladesh: Survival strategies and adjustments, Disasters 13(4): 300-314.

SIDDIKI, U.R. 2002. Riverbank Erosion, Population Displacement and its Impact on Socio-Economic Condition: A Case Study of the Jamuna River in Manikganj District, Master's Thesis, Department of Geography and Environment, Jahangirnagar University.

TALEB, M.A. 2007. Geomorphological and Hydrological Investigation of Riverbank Erosion: A Case of the Meghan River at Haimchar area, Chandpur District, Bangladesh, Master's Thesis, Department of Geography and Environment, University of Dhaka, Bangladesh.

ZAMAN, M.1989. The socio-economic and political context of adjustment to riverbank erosion hazard and population resettlement in Bangladesh, Human Organization, 48(3): 196-7

Manuscript received on 18.12.08 Accepted on 29.7.10

The Chittagong University Journal of Biological Sciences, Vol. 4( 1 \& 2): Page no : 25-39 